\title{
НОВЫЕ ДАННЫЕ О МНОГОУРОВНЕВОМ ХАРАКТЕРЕ РАЗМЕЩЕНИЯ РЕНИЕВОГО ОРУДЕНЕНИЯ В ОСАДОЧНОМ ЧЕХЛЕ ВОСТОЧНО- ЕВРОПЕЙСКОЙ ПЛАТФОРМЫ И ВАЛА КАРПИНСКОГО
}

\author{
С. Ю. Енгалычев \\ Всероссийский научно-исследовательский геологический институт \\ им. А. П. Карпинского, г. Санкт-Петербург
}

Поступила в редакцию 18 июля 2019 г.

\begin{abstract}
Аннотация: статья основана на новых авторских материалах и литературных данных по рениеносности осадочного чехла Восточно-Европейской платформы и вала Карпинского. Анализ материалов свидетельствует о том, что в пределах региона расположены районы, где рениевое оруденение присутствует на нескольких уровнях разреза осадочного чехла. В качестве таковых рассматриваются Жигулевский район, Калмыкский район и Донецкая зона. Дана их подробная характеристика. Также приводится описание Ижорской и Нижнекамской зон, для которых предполагается наличие рениевого оруденения на нескольких уровнях разреза. В работе показано, что каждый из выделенных районов имеет свои индивидуальные черты, однако, для всех из них характерно наличие крупных разрывных нарушений, проявленных в осадочном чехле и фундаменте. Многоуровневый характер размещения рениевого оруденения в осадочном чехле может указывать на возможность обнаружения оруденения на других, более глубоких, уровнях разреза.
\end{abstract}

Ключевые слова: рений, осадочный чехол Восточно-Европейской платформы, вал Карпинского, металлогения платформ.

\section{NEW DATA ON MULTILEVEL RENIUM MINERALIZATION LOCATION IN THE SEDI- MENTARY COVER OF THE EAST EUROPEAN PLATFORM AND KARPINSKY SWELL}

\begin{abstract}
: the paper is based on new author's materials and literature data concerning the rhenium potential of the sedimentary cover of the East European Platform and the Karpinsky Swell. Analysis of the materials suggests that within the region there are areas where rhenium mineralization is located at several levels of the sedimentary cover section such as the Zhiguli district, the Kalmyk district, and the Donetsk zone. Their detailed characteristic is given. Besides, the Izhora and Nizhnekamsk zones have been described for which the rhenium mineralization is assumed to occur at several levels of the section. It is shown that each of the identified areas has its own peculiar features, but in all of them, there are large faults in the sedimentary cover and the basement. The multilevel occurrence of the rhenium mineralization in the sedimentary cover may indicate the possibility of discovering the mineralization at other, deeper levels of the section.

Keywords: Rhenium, sedimentary cover of the East European platform, Karpinsky Swell, metallogeny of platforms.
\end{abstract}

\section{Введение}

Редкий металл рений (Re) обладает уникальными каталитическими и жаропрочными свойствами. Он используется в различных областях промышленности (машиностроение, авиация, космическая промышленность, переработка углеводородов), при этом спрос на него высок и продолжает расти [1]. В настоящее время основным сырьевым источником $\mathrm{Re}$ являются молибденовые, медно-молибденовые порфировые месторождения, медистые песчаники, a также эпигенетические урановые месторождения, связанные с зонами пластового окисления. В качестве альтернативных источников рассматриваются: фумаролы современных вулканов, углеродистые сланцы, нефти и битумы [2-5].

В Российской Федерации рений внесен в перечень стратегического минерального сырья, однако, его минеральное сырьевая база не сформирована. Ограниченные перспективы выявления объектов традиционного типа заставляют ориентироваться на поиски 
альтернативных видов сырья [5-8].

Особый интерес к территории Восточно-Европейской платформы с позиции поисков рениевого оруденения определяется рениевой специализацией некоторых углеродистых сланцев (диктионемовые, кукерситы, волжские и другие) и углей (Донбасс) региона [9] и нефтей Волго-Уральской провинции [10], а также наличием в осадочном чехле Re-Mo-U Брикетно-Желтухинского и Бельского месторождений $[7,8]$.

В 2012-2014 гг. «Роснедра» инициировали проведение поисковых работ на Re и попутные компоненты в углеродистых диктионемовых сланцах нижнего ордовика Прибалтийского бассейна на западе Ленинградской области (Кайболово-Гостилицкая площадь) [5] и на уран-редкометалльных объектах Подмосковного бассейна $[7,8]$.

Восточно-Европейская платформа (ВЕП) имеет сложную современную структуру, сформировавшуюся в результате длительной истории развития от архея до антропогена [11]. По особенностям строения структурных форм и типу слагающих их формаций в осадочном чехле выделяется два структурных этажа, отвечающих двум основным периодам формирования осадочного чехла [11]. Нижний этаж рифей-нижневендский характеризуется наличием линейных структур - авлакогенов, грабенов различного строения и прогибов, выполненных преимущественно терригенными и вулканогенными формациями, и верхний этаж - верхневендско-неогеновый, который, в свою очередь, подразделяется на два подэтажа: верхневендско-нижнетриасовый (нижнеюрский) и верхний среднеюрско-неогеновый [11]. Осадочный чехол ВЕП представлен отложениями верхневендско-неогенового (плитного) структурного этажа который подразделяется на два подэтажа: верхневендско-нижнетриасовый (нижнеюрский) и среднеюрско-неогеновый [11].

До последнего времени не проводились исследования по региональному обобщению материалов по рениеносности осадочного чехла Восточно-Европейской платформы и выявлению особенностей его размещения, а поисковые работы проводились на уранредкометалльных объектах, рениеносность которых ранее была изучена очень слабо.

В анализ также были вовлечены данные по объектам, находящимся на территории вала Карпинского, являющегося с одной стороны пограничной структурой между платформой и Скифской (СкифскоТуранской) плитой, а с другой стороны, частью линейной Припятско-Доно-Мангышлакской складчатой системы [11]. Такое решение оправдывается расположением вала Карпинского, Складчатого Донбасса и Днепровско-Донецкой впадины в пределах единой крупной тектонической структуры - линеамента Карпинского [12].

Цель статьи состоит в обосновании многоуровне- вого характера размещения рениевого оруденения в осадочном чехле Восточно-Европейской платформы и вала Карпинского по полученным новым данным.

Фактическим материалом для написания статьи стали литературные и фондовые данные по геологии и металлогении рассматриваемого региона, а также собственные материалы автора, полученные при исследовании рениевого оруденения на территории Среднего Поволжья в районе Жигулей, в Калмыкии, на северо-западе России (Ленинградская, Псковская область) и в Татарстане.

\section{Методика исследования}

Важным методическим принципом, используемым в настоящей статье, является представление о проницаемости осадочного чехла, его неразрывной историко-геологической и структурной связи с раннедокембрийским фундаментом и существенной роли тектонических нарушений, являющихся каналами для вертикальной миграции флюидов.

Первоначально был выполнен сбор и систематизация литературных, фондовых и авторских материалов рениеносности осадочного чехла региона.

Для получения сведений о вещественном составе рениевого оруденения и рудовмещающих отложений были использованы: петрографический метод, электронная микроскопия с количественным определением составов минеральных фаз (сканирующих электронный микроскоп CamScan MX 2500S с микрозондом), рентгенофазовый анализ (рентгеновский дифрактометр ДРОН-6). Химический состав был определен методом ICP-MS в сертифицированной Центральной аналитической лаборатории ФГБУ «ВСЕГЕИ». Химический состав определен на приборе Agilent 7700x. Для части проб получены данные о содержании широкого круга химических элементов (U, Mo, V, Se, Ni, Co, Cu, Pb, As, Ag и др.).

При анализе данных использовались разномасштабные геологические и структурные карты, карты раннедокембрийского фундамента, палеогеографические, гидрогеологические и палеогидрогеологические данные, материалы по эпигенетическим изменениям, а также многочисленные данные по минерагении осадочного чехла и фундамента и нефтегазоносности территории.

\section{Результаты исследований}

В ходе анализа материалов по рениеносности осадочного чехла ВЕП было выявлено, что объекты с рениевой специализацией часто совмещены в пространстве и располагаются в пределах единых тектонических зон, где локализованы на нескольких уровнях разреза осадочного чехла.

Остановимся на краткой характеристике трех наиболее изученных территорий, в пределах которых выявлен многоуровневый характер размещения рениевого оруденения (рис. 1). 

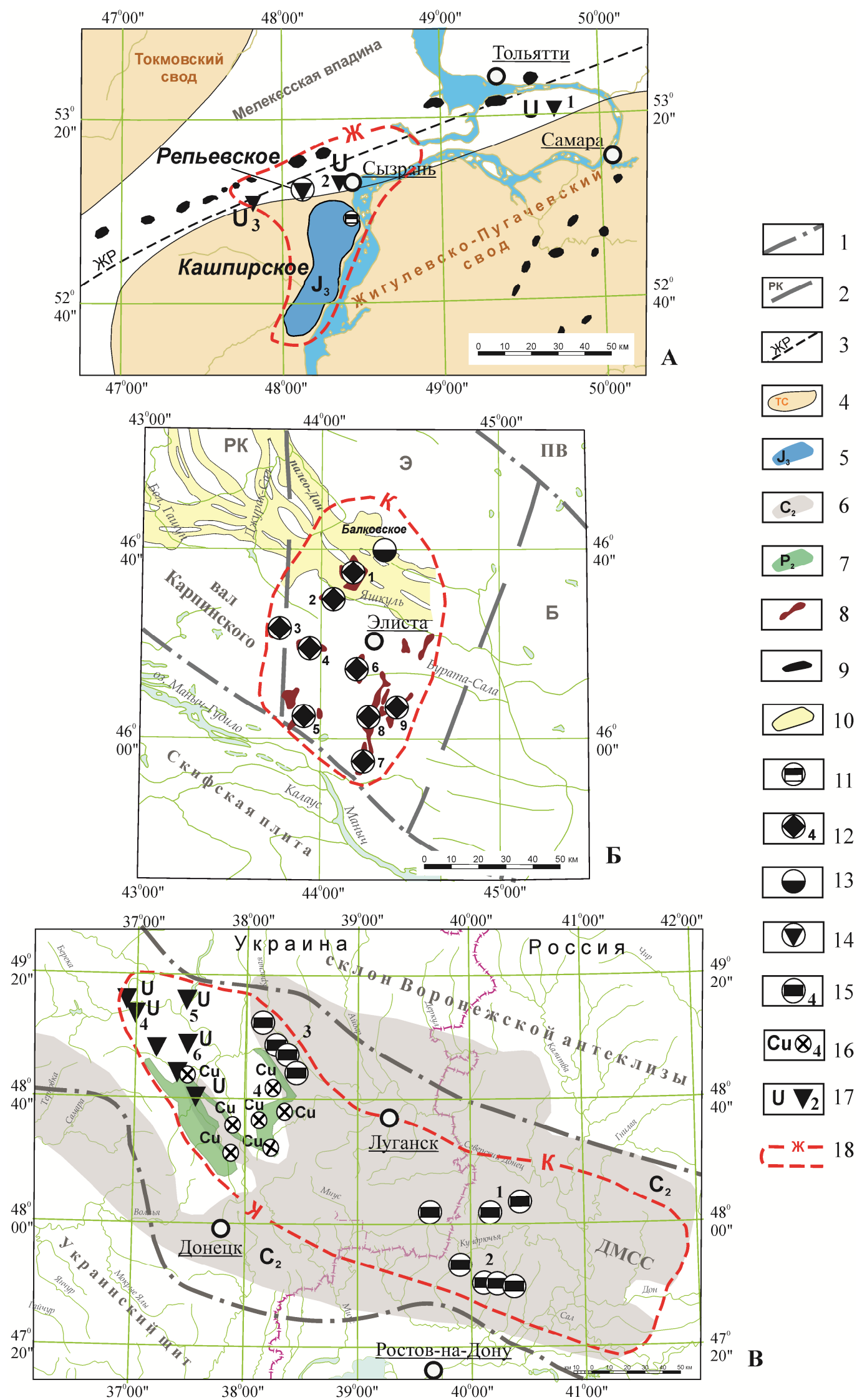

Pис. 1. Районы, в пределах которых рениевое оруденение размещается на нескольких уровнях разреза осадочного чехла: Жигулевский (А), Калмыкский (Б) районы и Донецкая зона (В). 1 - границы плит, щитов и складчатых областей (ПВ - Прикаспийская впадина Восточно-Европейской платформы, ДМСС - Доно-Манычская складчатая система); 2 - границы блоков вала 
Карпинского и их названия ( $P К$ - Ремонтненский; Э - Элистинский; 5 - Бузулукский); 3 - Жигулевский разлом; 4 - своды антеклиз; 5-8 - породы специализированные и потенциально специализированные на рений: 5 - горючие сланцы Кашпирского месторождения (верхняя юра, Волжский бассейн); 6 - угли среднего карбона Донбасса; 7 - пермские медистые песчаники Бахмутской и Кальмиус-Торецкой котловины (Донецкая зона); 8 - органогенно-фосфатные уран-редкометалльные месторождения в отложениях майкопской серии, связанные с костным детритом (Калмыкский район); 9 - нефтяные месторождения; 10 - эрозионная система палеоДона, выполненная отложениями миоцена на территории вала Карпинского; $11-15$ - рениевое оруденение: 11 - в горючих сланцахкукерситах; 12 - в органогенно-фосфатных редкометалльных рудах вала Карпинского (цифрой обозначены комплексные органогенно-фосфатные уран-редкометалльные месторождения: 1 - Яшкульское, 2 - Троицкое, 3 - Шаргадыкское, 4 - Богородское, 5 Степное, 6 - Северо-Харабулукское, 7 - Нургинское, 8 - Центральное, 9 - Багабурульская группа месторождений - Багабурульское, Прудовое, Южно-Буратинское, Северо-восточная часть Багабурульского рудного поля, Вишневское); 13 - в песчаниках в связи с зонами окисления; 14 - в уран-битумных рудах в карбонатных толщах в связи с зонами восстановления; 15 - в углях (групп угольных месторождений Донецкой зоны содержащие повышенные концентрации рения: 1 - Гуково-Зверевская; 2 - ШахтинскоНесветаевская; 3 - Лисичанская); 16-17 -перспективные на рений месторождения и проявления ряда полезных ископаемых (уран, горючие сланцы, редкие металлы и др.); 16 - проявления медистых песчаников и сланцев и их номера (4 - Берестянское проявление); 17 - уран-битумные месторождения (4 - Берекское, 5 - Краснооскольское, 6 - Адамовское) и проявления ( 1 - Могутовское, 2 - Сызранское, 3 - Новоспасское); 18 - районы и зоны с размещением рениевого оруденения на нескольких уровнях разреза (Ж Жигулевский район, $K$ - Калмыкский район, Д- Донецкая зона).

1. Жигулевский район расположен в Среднем Поволжье в районе г. Сызрань. В тектоническом отношении приурочен к северо-западному склону Жигулевско-Пугачевского свода, осложненному Жигулевским валом который представляет собой флексуроподобную складку длиной 360 км и шириной 10-20 км (рис. 1). С севера вал ограничен одноименным глубинным разломом, проявленным в кристаллическом фундаменте. Дислокации в пределах Жигулевского разлома формировались в палеозойский период, а в мезозое, а затем в кайнозое по этому разлому прошли более интенсивные вертикальные перемещения.

Осадочный чехол Жигулевско-Пугачевского свода представлен мощной, более 1,5 км толщей пород, которые сформировались в два тектоно-седиментационных этапа: средне-позднепалеозойский $\left(\mathrm{D}_{2}-\mathrm{P}_{2}\right)$ и мезозойско-кайнозойский $\left(\mathrm{J}_{2}-\mathrm{Q}\right)$. Этапы разделены длительным стратиграфическим перерывом $\left(\mathrm{T}-\mathrm{J}_{2}\right)$.

В разрезе осадочного чехла выделяется два потенциально рениеносных уровня. Первый представлен уран-битумными объектами, расположенными в полосе Жигулевского вала в карбонатных отложениях верхнего карбона, а второй - горючими сланцами волжского яруса верхней юры.

Уран-битумное оруденение связано с твердыми битумами в кавернозных доломитизированных известняках и доломитах репьевского горизонта гжельского яруса верхнего карбона $[13,14]$. В районе установлено четыре уран-битумного проявления (Новоспасское, Сызранское, Зольское, Красноярское) и одно Репьевское месторождение урана. Оно состоит из трех сближенных рудных залежей пластообразной и линзовидной формы. Содержания урана - от 0,019 до $0,397 \%$ при бортовом $0,01 \%$. Глубина размещения рудных залежей - от 40 до 120 м, а их мощность от 0,1 м до 16 м. Помимо $U$ в рудах установлены повышенные содержания (в \%) Мо до $0,5, \mathrm{Cu}$ до $0,01, \mathrm{Ni}$ и $\mathrm{Co} 0,003, \mathrm{Zn}$ $0,1, \mathrm{~Pb} 0,15, \mathrm{~V}$ 0,6, As до 0,15, Se до 0,09, Ag 0,0008. Автором впервые в составе руд установлены высокие содержания $\operatorname{Re}($ до 6 г/т). Анализ авторских материалов по составу руд и вмещающих пород позволил выявить положительные корреляционные связи между $\mathrm{Re}$ и группой элементов - V, Mo, Se. Оруденение имеет верхнеюрский возраст (160 млн лет, верхняя юра) и связано с эксфильтрацией термальных вод.

Вторым рениеносным уровнем являются углеродистые горючие сланцы Волжского сланцевого бассейна, приуроченные к толще средневолжского подъяруса верхней юры. В непосредственной близости от Репьевского уран-битумного месторождения располагаются залежи горючих сланцев крупного Кашпирского месторождения, содержащие повышенные концентрации рения [15]. Разведанные запасы сланцев этого месторождения составляют 2,17 млрд т. Сланценосная толща состоит из 6-9 слоев горючих сланцев, объединенных в три пласта, толщиной $0,1-1,4$; $0,1-2,8 ; 0,1-1,0$ м. Ранее в них было установлено содержание $0,016-0,22$ г/т $\operatorname{Re}[15]$. По сравнению с вмещающими глинами, в горючих сланцах фиксируются повышенные содержания S, Se, Mo, Ni, Ag, V, P [16].

Обращает на себя внимание позднеюрский возраст формирования Репьевского уран-битумного месторождения и горючих сланцев. Можно полагать, что рений поступал в позднеюрский палеобассейна при разгрузке восходящих термальных вод, участвующих в формировании уран-битумных объектов Жигулевского района, и в последующем фиксировался в углеродистых осадках.

2. Калмыкский район расположен на территории Республики Калмыкия и, частично, в Ростовской области. В тектоническом отношении район приурочен к Элистинскому мегаблоку вала Карпинского (рис. 1).

Здесь выделяется два потенциально рениеносных уровня: «ергенинский» (органогенно-фосфатные уран-редкометалльные руды, связанные со скоплениями костного детрита в глинах майкопской серии верхнего олигоцена) и «яшкульский» (эпигенетические урановые объекты в проницаемых отложениях миоцена).

К ергенинскому уровню приурочены уникальные по своему составу и строению органогенно-фосфатные уран-редкометальные залежи, сложенные урансодержащим костным детритом $[17,18]$. Они слагают относительно маломощные (дециметры, первые метры), но протяженные (многие километры) пластообразные тела, заключенные в мощной глинистой толще. Выделено 13 месторождений (Степное, залежи Центральная, Яшкульско-Троицкая, Воробьевская, 
Нугринская, Северо-Харабулукская, Прудово-Южнобуратинская, Багабурульская, Шаргадыкская, Богородская и др.), десятки рудопроявлений и многочисленные пункты минерализации. Глубина залегания рудных горизонтов, сложенных костным, детритом колеблется от 170 до 900 м.

Основными компонентами руд являются: костный детрит рыб (фторапатит, франколит), пирит, сидерит и глинистый материал. Руды обогащены ураном, редкими землями, скандием и рением. Рений постоянно присутствует в рудах, среднее содержание составляет от 0,2-1,4 до 3,98 г/т [17, 19]. Его повышенные значения (1,5-2 г/т) приурочены к высокосернистым рудам и породам, обогащенным сульфидами железа. Re coдержится, вероятнее всего, в тонкорассеянном сульфидном материале, образуя субмикронные (наноразмерные) выделения.

Исходя из современных представлений [18], формирование органогенно-фосфатных уран-редкометалльных залежей связано с неоднократным проявлением в осадочном бассейне подводной вулканической деятельности которая приводила к массовой гибели ихтиофауны. Последующий неоднократный перемыв и переотложение костного детрита рыб на склонах активизированных поднятий приводили к формированию рудных залежей. Осаждение рудных компонентов (в том числе Re) из флюидов происходило на геохимических барьерах.

Яшкульский потенциально рениеносный уровень приурочен к отложениям одноименной серии, выполняющим миоценовые палеоврезы низовьев системы палео-Дона. Яшкульская серия представлена песчаными отложениями, которые с несогласием залегают на отложениях майкопской серии верхнего олигоцена - нижнего миоцена.

Здесь установлено Балковское месторождение урана и ряд проявлений [19]. Оно включает зоны пластового окисления (пластовой и кулисно-линзовидной морфологии), связанные с нисходящей инфильтрацией подземных вод [19]. Рений фиксируется в породах, обогащенных $\mathrm{Se}$ и U. B исследованных пробах установлены содержания Re в интервале $<0,005-0,44$ г/т и лишь в гальках фосфатного состава они достигают 1,43 г/т. Наиболее устойчивые повышенные содержания $(0,1-0,44$ г/т) приурочены к сероцветным породам на границах зон пластового окисления. Источником рения, вероятнее всего, являются специализированные на уран (а также молибден и рений) нижележащие отложения майкопской серии.

3. Донецкая зона располагается в Ростовской области и на Украине (рис. 1). В геолого-структурном отношении зона находится на территории Складчатого Донбасса и, частично, Днепровско-Донецкой впадины. Важную роль в строении территории играют разрывные нарушения, во многих случаях определяющие границы геологических структур и контролирующие размещение оруденения.

В строении разреза осадочного чехла Донбасса принимают участие образования нижнего, среднего палеозоя, карбона, перми, триаса, мела, палеогена и неогена. Рассматриваемая территория испытала несколько этапов тектоно-магматической активизации и имеет специфический металлогенический профиль: ртуть (Никитовское, Константиновское и другие месторождения), полиметаллы, медь (медистые песчаники), соль, битумы, уран, золото. При этом угли среднего карбона Донецкого бассейна, по сравнению с остальными углями России, имеют рениевую специализацию (содержания Re в углях 0,4-0,7 г/т) [9].

Основной рениеносный уровень связан со среднекаменноугольными углями и угленосными отложениями Донецкого каменноугольного бассейна. В качестве потенциального выделяется нижнепермский уровень, приуроченный к медистым песчаникам и сланцам Бахмутской котловины.

По данным массового опробования углей Восточного Донбасса было установлены повышенные (до 0,7 г/т) содержания Re [20], в ассоциации с $\mathrm{Ag}, \mathrm{V}, \mathrm{Ni}, \mathrm{Zn}$, $\mathrm{Pb}, \mathrm{Cu}$ и $\mathrm{Hg}$. Рениеносность характерна для приразломных зон, имеющих поперечную ориентировку по отношению к основному простиранию складок. Вероятнее всего, рений мигрировал по тектоническим нарушениям из глубинных зон в виде металлоносных рассолов и фиксировался в угленосных отложениях. При этом возможно локальное перераспределение рения в пределах угленосной толщи. Часть рения, вероятно, могла накапливаться в отложениях, обогащенных углеродом на син-диагенетическом этапе при поступлении редких элементов из активизированных рифтогенных зон в область накопления торфов, а также присутствовать в составе вулканических пеплов, о существовании которых свидетельствуют многочисленные прослои преобразованных пепловых образований - тонштейнов.

Нижнепермский потенциально рениеносный уровень связан с медистыми песчаниками и сланцами, расположенными в северо-западной части зоны в пределах Бахмутской и северной части КальмиусТорецкой котловин, в зоне сочленения ДнепровскоДонецкой впадины и Складчатого Донбасса. Здесь известны стратиформные (медистые песчаники) рудопроявления меди. Одним из наиболее изученных и перспективных является Берестянское рудопроявление $\mathrm{Cu}$, в рудах которого установлены повышение содержания $\mathrm{Zn}, \mathrm{Pb}, \mathrm{Ni}, \mathrm{Ga}, \mathrm{Ag}, \mathrm{Re}, \mathrm{Au}, \mathrm{Pb}[21]$.

Кроме того, перспективным объектом на рений можно считать краевые зоны соляных куполов, развитых в зоне сочленения Днепровско-Донецкой впадины и Складчатого Донбасса, где развито эпигенетическое уран-битумное оруденение в терригенных отложениях в связи с зонами восстановительных условий. Здесь располагается группа уран-битумных месторождений - Адамовское, Краснооскольское, Берекское и ряд проявлений: Петровское, Ново-Дмитриевское, Бантышевское, Ново-Троицкое [21]. Для уранбитумных руд Адамовского месторождения характерны элементы-спутники урана: Mo, Cr. Отмечены также повышенные содержания $\mathrm{As}, \mathrm{Zn}, \mathrm{Pb}, \mathrm{Hg}, \mathrm{Re}, \mathrm{Se}$. 
Предполагается формирование урано-битумного оруденения в результате взаимодействия кислородных грунтовых вод с углеводородсодержащими гидротермальными растворами.

В рамках исследования были выделены слабоизученные зоны с потенциальным размещением ре- ниевого оруденения на нескольких уровнях разреза. Анализ имеющихся материалов показал, что на ВЕП в качестве таковых можно рассматривать Ижорскую и Нижнекамскую зоны (рис. 2). Однако рениеносность этих территорий требует дополнительного исследования.
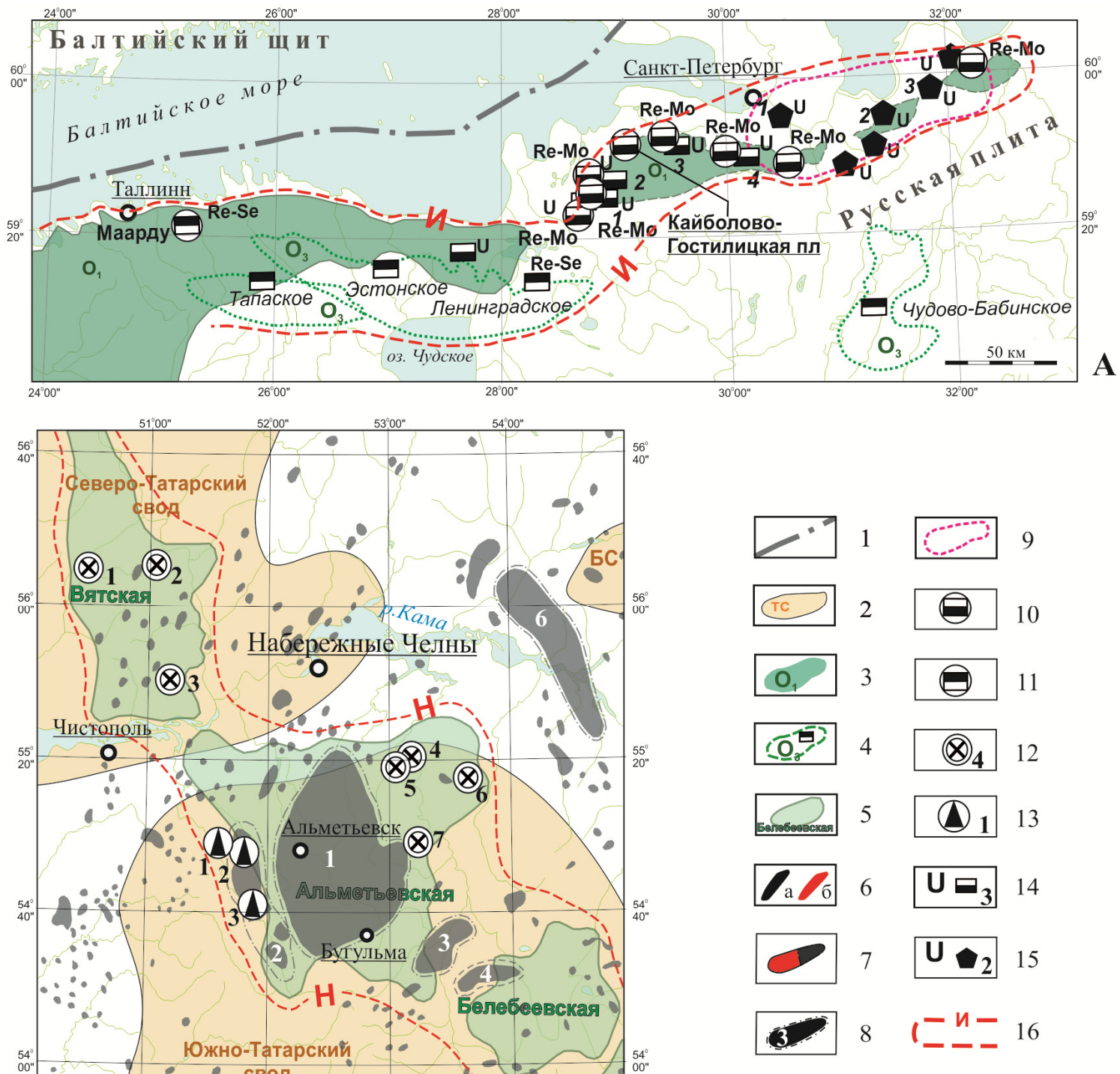

Puc. 2. Слабоизученные на рений Ижорская (А) и Нижнекамская (Б) зоны: 1 - границы плит и щитов; 2 - своды ВолгоУральской антеклизы (БС - Башкирский свод); 3 - область распространения диктионемовых сланцев нижнего ордовика; 4 - контуры месторождений горючих сланцев-кукерситов верхнего ордовика; 5 - меденосные площади в пермских отложениях; 6 - нефтяные (а), газовые и газоконденсатные (б) месторождения; 7 - нефтегазовые и нефтегазоконденсатные месторождения; 8 - уникальные и крупнейшие месторождения нефти ( 1 - Ромашкинское, 2 - Новоелховское, 3 - Туймазы, 4 - Бавлы, 5 - Шпаковское, 6 - Арлан); 9 - область распространения специализированных на уран объектов в базальных песчаниках венда и коре выветривания фундамента на территории Ижорской зоны; 10-12 - рениевое оруденение; 10 - в битуминозных сланцах; 11 - в горючих сланцах; 12 в медистых песчаниках (1 - Шемордан, 2 - Кукмор, 3 - Мамадыш, 4 - Азнакаево, 5 - Сарманово, 6 - Чатыр-Тау, 7 - Муслюмово); 13 - в связи с жидкими углеводородами (1 - Лангуевское, 2 - Ашальчинское, 3 - Мордово-Кармальское); 14 - месторождения урана в диктионемовых сланцах (1 - Котловское, 2 - Куммоловское, 3 - Гостилицкое, 4 - Красносельское); 15 - урановые месторождения в венде ( 1 - Славянское, 2 - Рябиновское, 3 - Ратницкое) и проявления (без номера); 16 - границы слабоизученных зон с потенциальным размещением рениевого оруденения на нескольких уровнях разреза (И - Ижорская, $H$ - Нижнекамская). 
Ижорская зона располагается на территории Ленинградской и Псковской областей и в Северной Эстонии в полосе Балтийско-Ладожского глинта. В тектоническом отношении она приурочена к краевой части ВЕП.

Основной рениеносный уровень Ижорской зоны приурочен к нижнеордовикским углеродистым диктионемовым сланцам. Последние представлены микрогоризонтально-слоистыми смолисто-черными аргиллитами мощностью $0,5-4$ м. Они характеризуются комплексной рудоносностью (U, Mo, V, Re Sc, Cs, Ag) [5], обогащены ртутью и благородными металлами (Pd до 1,1; Pt до 0,065 г/т, Au до 0,43; Ag до 300 г/т). Средние содержания Re по всем исследованным разрезам вдоль полосы Балтийско-Ладожского глинта составляют 0,12 г/т. Рений в сланцах ассоциирует с органическим и сульфидным веществом, а также Мо, $\mathrm{V}, \mathrm{U}, \mathrm{Cu}, \mathrm{Co}, \mathrm{Ni}, \mathrm{Pb}$ и Ag. Рений присутствует в виде примеси в составе сульфидной (пирит, марказит, халькопирит, галенит) минерализации, присутствующей в сланцах в виде тонкой примеси или в виде конкреций или сливных сульфидных прослоев.

В толще сланцев выявлены непромышленные месторождения урана - Ранноловское, Котловское, Кайболовское, Куммоловское, Гостилицкое, Красносельское [14]. Содержание урана в сланцах колеблется от 0,018 до $0,028 \%$ на мощность 1,2-2,2 м.

Также можно выделить два потенциальных рениеносных уровня: вендский уровень, локализованный в базальных песчаниках венда $\left(\mathrm{V}_{2}\right)$ и коре выветривания фундамента, а также верхнеордовикский - приуроченный к горючим кукерситам.

С вендским уровнем связаны три месторождения урана (Рябиновское, Ратницкое, Славянское), ряд проявлений и пунктов урановой минерализации [22]. Все урановые объекты размещаются вблизи предвендской поверхности несогласия, в основании осадочного чехла на глубине 250-400 м. Обращает на себя внимание расположение этих урановых объектов, связанных с предвендским несогласием, непосредственно в полосе Балтийско-Ладожского глинта, где располагается область развития диктионемовых сланцев.

Верхнеордовикский уровень приурочен к пачке горючих сланцев - кукерситов Прибалтийского сланцевого бассейна. Сланцы-кукерситы образуют до 30 слоев и прослоев мощностью от нескольких сантиметров до 0,6-0,9 м. В районе известны Ленинградское, Эстонское и Тапаское месторождения. Содержание Re в сланцах-кукерситах невысоки - от 0,0032 до 0,024 г/т.

Нижнекамская зона располагается на территории Кировской области, Татарстана, и Башкирии (рис. 2). В тектоническом отношении она приурочена к краевым зонам Северо-Татарского и Южно-Татарского сводов Волго-Уральской антеклизы.

Верхнепермский потенциально рениеносный уровень связан со стратиформным медным оруденением в отложениях уфимского, казанского и татарского яруса перми. В пределах зоны располагается несколько меденосных площадей: Вятская, Альметьевская, Белебеевская, Стерлибашевская обеденных в ВятскоКамскую медоносную зону [23]. Меденосные площади контролируются валообразными поднятиями, фиксирующимися по опорным горизонтам пермских отложений, и отсутствуют над депрессиями. В пределах таких поднятий положение медного оруденения определяется брахиантиклинальными структурами низких порядков. В медистых песчаниках установлены повышенные содержания V (до $1 \%$ ), $\mathrm{Ag}$ (до 10 г/т), $\mathrm{Pb}$ и $\mathrm{Zn}$ (до 2-3 \%), Cd, Ge, Se, Te, Co, Re [24]. Ранее в медных рудах на территории Татарстана были выявлены повышенные содержания благородных металлов (платина, палладий) [25].

Автором впервые были проанализированы на $\mathrm{Re}$ типовые разности медистых песчаников северной части Вятской (участок Кукмор, Мамадыш, Шемордан) и Альметьевской меденосных зон (участок Сарманово, Азнакаево и рудное поле Чатыр-Тау). Наиболее высокие содержания Re были установлены в медных рудах на территории рудного Чатыр-Тау (до 0,42 г/т), в ассоциации с Мo, Ag, а также в медистом сланце участка Мамадыш $(0,22$ г/т), на участках Кукмор и Шемордан 0,02-0,12 г/т. При этом, в образцах, кроме меди, фиксируются повышенные концентрации V, Se, $\mathrm{Ag}$, а также $\mathrm{Hg}$ и $\mathrm{Au}$.

Рассматриваются два источника $\operatorname{Re}$ и ряда редких элементов в медистых песчаниках: 1) Уральская складчатая система, являющаяся источником обломочного материала для пермских терригенных отложений; 2) воды и рассолы глубинной циркуляции (в том числе термальные и металлоносные), сопровождающие нефтяные месторождения.

Повышенные содержания Re установлены в некоторых месторождениях углеводородов, расположенных в пределах рассматриваемой зоны. Так, в частности, в высоковязких нефтях следующих месторождений (г/т): Лангуевского - 0,017, Ашальчинского 0,018, Мордово-Кармальского - 0,1 [3]. В литературе приводятся сведения о наличии $\operatorname{Re}($ до 0,2 г/т) в смолистых нефтях Татарстана, однако, сведения по конкретным месторождениям отсутствуют [26]. Нефти Волго-Уральской провинции имеют рениевую специализацию по сравнению с нефтями других провинций России [10].

Таким образом, в Нижнекамской зоне проявлена пространственная связь пермских медистых песчаников с залежами нефти (девон - карбон). Установлены повышенные содержаниями Re в медистых песчаниках и в некоторых месторождениях нефти. Можно полагать, что и другие месторождения нефти, расположенные в полосе развития медистых песчаников, могут быть обогащены рением. Нельзя исключать, что и более глубокие уровни разреза, а также в подземные воды глубокой циркуляции могут быть обогащены рением.

Многоуровневый характер размещения уранового оруденения ранее был установлен для ряда районов 
европейской части России [27]. Такие районы получили название многоуровневых, так как оруденение располагается на нескольких уровнях разреза. Рудонасыщенность и разнообразие типов оруденения позволяет рассматривать такие районы в качестве особых перспективных территорий, рудный потенциал которых не раскрыт в полной мере.

В контексте определения подходов для выделения многоуровневых районов (зон), интересные сведения приведены в работе В.С. Салихова [28], в которой предложена концепция формирования медного оруденения различных геолого-промышленных типов в единых зонах земной коры. Основная идея состоит в рассмотрении таких структурных зон как единых самоорганизующихся рудоносных систем, имеющих длительное развитие. Несложно заметить, что такие системы имеют многоуровневое строение, а более позднее оруденение было сформировано за счет более раннего.

Анализ разноплановых материалов по описанным выше районам (или зонам), где наблюдается многоуровневый характер размещения рениевого оруденения, свидетельствует об их яркой индивидуальности и своеобразии, что препятствует разработке единой модели их формирования. Примерами таких районов служат Вятско-Камская впадина и Воронежская антеклиза [29, 30].

Однако для каждого из них характерен структурный контроль, проявленный в наличии одного или нескольких секущих тектонических нарушений (разломы, надвиги, зоны трещинноватости, зоны брекчирования и др.) в осадочном чехле и, возможно, кристаллическом фундаменте. Такие нарушения сплошности осадочных толщ, часто имеющие рифтогенную природу, могут являться «каналами» вертикальной миграции и, возможно, циркуляции флюидов. К ним могут быть приурочены участки «флюидных разгрузок», выраженные в виде грязевых вулканов, термальных источников, углеводородных «сипов» и др. В силу особенностей геологического строения такие районы имеют «особые» гидрогеологические условия: здесь могут наблюдаться контрастные изменения в химическом и газовом составе подземных вод, их динамики и температуры. При этом все эти параметры влияют на характер проявления эпигенетических процессов.

Одним из механизмов формирования оруденения на нескольких уровнях разреза можно рассматривать механизм «наследования», когда за счет более древнего оруденения, в ходе его перераспределения, при участии эпигенетических процессов, формируются новые объекты.

\section{Заключение}

В результате обобщения литературных и авторских материалов по рениеносности ВосточноЕвропейской платформы и вала Карпинского установлено, что в пределах региона располагаются территории, где рениевое оруденение располагается на нескольких уровнях разреза. Это относится к Жигулевскому и Калмыкскому районам, Донецкой зоне, а также к Ижорской и Нижнекамской зонам, для которых предполагается наличие рениевого оруденения на нескольких уровнях разреза.

Наличие оруденения на двух уровнях в осадочном чехле позволяет высказать предположение о наличии оруденения и на более глубоких уровнях осадочного чехла и в кристаллическом фундаменте. Высокий прогностический ресурс таких территорий на рений позволяет обосновать вывод о целесообразности их дальнейшего исследования.

Новые материалы, свидетельствующие о многоуровневом характере размещения рениевого оруденения в осадочном чехле в пределах определенных районов и зон, вносят вклад в металлогению платформенных областей.

\section{ЛИТЕРАТУРА}

1. Мелентьев, Г. Б. Ресурсно-экологические проблемы создания производства рения в России и перспективы их решения / Г. Б. Мелентьев, И. Д. Трошкина, А. А. Зубков // Экология промышленного производства. - 2011. - №4. C. $2-15$.

2. Торикова, М. В. Рений в промышленных и природных углеводородных фракциях, и углеродсодержащих месторождениях / М. В. Торикова, Ю. А. Кудинов, Д. С. Ключарев // Органическая минералогия: Тезисы II Рос. совещ. по органической минералогии. - Петрозаводск: ИГ КарНЦ PAH, - 2005. - C. 191-193.

3. Палант, А. А. Металлургия рения / А. А. Палант, И. Д. Трошкина, А. М. Чекмарев. - М.: Наука, 2007. - 298 с.

4. Трошкина, И. Д. Рений в нетрадиционном сырье: распределение и возможность извлечения / И. Д. Трошкина, А. В. Шиляев, Т. Г. Абдрахманов, А. Б. Майборода // Разведка и охрана недр. - 2011. - № 6. - С. 87-90.

5. Вялов, В. И. Рений в диктионемовых сланцах Прибалтийского бассейна / В. И. Вялов, А. С. Балахонова, А. И. Ларичев, А. Х. Богомолов // Вестник Моск. ун-та. Сер. 4. Геология. -2013 . - № 2. - С. 63-68.

6. Трач, Г. Н. Ресурсный потенциал рения территории России / Г. Н. Трач, С. М. Бескин // Разведка и охрана недр. 2011. - №6. - С. 26-33.

7. Кременеикий, А. А. Бельское Re-Mo-U месторождение: минералого-геохимические особенности, условия формирования, технология извлечения рения / А. А. Кременецкий, Н. В. Лунева, И. М. Куликова // Разведка и охрана недр. 2011. - № 6. - С. 33-41.

8. Брикетно-Желтухинское месторождение рения - новый геолого-промышленный тип гидрогенных месторождений: особенности геологического строения и технология подземного выщелачивания / С. А. Карась [и др.] // Разведка и охрана недр. - 2016. - №11. - С. 20-26.

9. Геологический атлас России масштаб 1:10 000 000. Раздел 3. Полезные ископаемые и закономерности их размещения. Карта сланценосности и угленосности. Отв. ред. атласа: А. А. Смыслов; Всерос. н.-и. геол. ин-т им. А. П. Карпинского (ВСЕГЕИ), С.-Петерб. гос. горный ин-Т им. Г. В. Плеханова (техн. ун-т) (СПбГГИ), ВНИИ геологии и минер. ресурсов Мирового океана (ВНИИокеангеология) и др.. М.; СПб., 1996. - 202 с.

10. Готтих, Р. П. Геохимические особенности нефти различных регионов и возможный источник металлов в ней / 
Р. П. Готтих, Б. И. Писоцкий, Д. З. Журавлев // Докл. РАН. - 2008. - Т. 422. - № 1. - С. 88-92.

11. Геология и полезные ископаемые России. В шести томах. т. 1. Запад России и Урал. Кн. 1. Запад России / Под ред. Б. В. Петрова, В. П. Кирикова. - СПб., 2006. - 528 с.

12. Панов, Б. С. Глубинные разломы и минерагения линеамента Карпинского с позиций синергетического анализа / Б. С. Панов. - Преприн. ИГМР АН Украины, Киев, 1994. $74 \mathrm{c}$.

13. Тюленева, В. М. Оценка перспектив и критерии локализации урано-битумного оруденения в осадочном чехле Русской плиты (Среднее Приволжье) / В. М. Тюленева, В. Ф. Пеньков, Г. В. Комарова // Руды и металлы. - 1996. - №2. C 38-47.

14. Уран российских недр / Г. А. Машковцев [и др.].- М.: ВИМС, 2010. $-850 \mathrm{c}$.

15.. Рений в отложениях волжского яруса центральной части Волжского сланцевого бассейна / А. Г. Самойлов [и др.] // Изв. Сарат. ун-та. Нов. сер. Сер. Науки о Земле. - 2017. вып.17(1). - С.58-61.

16. Гаврилов, Ю. О. Седиментологические и геохимические обстановки формирования углеродистых толщ в мезозойских палеобассейнах европейской части России [Электронный ресурс] / Ю. О. Гаврилов, Е. В. Щепетова, Е. А. Щербинина // Георесурсы. Геоэнергетика. Геополитика. - 2014. - Вып. 1 (9). Режим доступа: http://www.oilgasjournal.ru/vol_9/gavrilov.html (дата обращения: 31.05.2018).

17. Столяров, A. С. Ергенинский ураново-редкометалльный район Калмыкии / А. С. Столяров, Е. И. Ивлева. - М.: ВИМС, 2008. - $170 \mathrm{c}$.

18. Шарков, А. А. Ураново-редкометалльные месторождения Мангышлака и Калмыкии, их генезис / А. А. Шарков. М.: «Эслан», 2008. - 220 с.

19. Расулова, С. Д. Особенности формирования Балковского экзогенно-эпигенетического инфильтрационного месторождения в отложениях миоцена / С. Д. Расулова, Г. А. Тарханова, Б. Ю. Каминов // Разведка и охрана недр. - 2008. № 11. - С. 18-23.

19. Особенности комплексных органо-фосфатных руд в Ергенинском районе Калмыкии / В. М. Тюленева [и др.] // Разведка и охрана недр. - 2014. - №7. - С. 6-12.

20. Жаров, Ю. Н. Ценные и токсичные элементы в товарных углях России / Ю. Н. Жаров, Е. С. Мейтов, И. Г. Шарова. -

ФГБУ Всероссийский научно-исследовательский геологический институт им. А. П. Карпинского, г. Санкт-Петербург

Енгальчев Святослав Юрьевич, кандидат геологоминералогических наук, старший научный сотрудник Email:_sleng2005@mail.ru

Тел.: +7 (812) 3289156
М.: Недра, 1996. -225 с.

21. Металлические и неметаллические полезные ископаемые Украины. Т. I: Металлические полезные ископаемые / Д. С. Гурский [и др.]; науч. ред. Н. П. Щербак, А. Б. Бобров. - Киев; Львов: Центр Европы, 2005. - 783 с.

22. Иванова, Т. А. Рябиновское месторождение и перспективы поисков уранового оруденения на северо-западе Русской плиты / Т. А. Иванова, Г.В.Грушевой // Материалы по геологии месторождений урана, редких и редкоземельных металлов. - 2010. - Вып. 155. - С. 61-71.

23. Халезов, А. Б. Перспективы и проблемы промышленного освоения месторождений меди верхнепермской красноцветной формации Западного Предуралья (способами подземного и кучного выщелачивания) / А. Б. Халезов // Руды и металлы. - 2011. - № 5. - С. 5-14.

24. О геохимических особенностях и условиях образования медистых песчаников и сланцев / Е. М. Поплавко [и др.] // Геохимия. -1977 . - № 8. - С. 1217-1233.

25. Геология твердых полезных ископаемых Республики Татарстан / под ред. Ф. М. Хайретдинова, Н. Б. Валитова. Казань: Изд-во «ДАС», 1999. - 403 с.

26. О концентрациях рения в нефтях, нефтяных битумах и горючих сланцах / Е. М. Поплавко [и др.] // Геохимия. 1974. - № 9. - С. 1399-1402.

27. Енгалычев, С. Ю. Многоуровневые урановорудные районы европейской части России / С. Ю. Енгалычев // Региональная геология и металлогения. - 2012. - № 49. C. $101-106$.

28. Салихов, В. С. О совмещении различных геологопромышленных типов медного оруденения в единых структурах земной коры / В. С. Салихов // Вестник Читинского Государственного университета. - 2011. - № 1 (68). - С. $128-131$.

29. Наумов, В. А. Ртутистое золото и амальгамы в мезозойкайнозойских отложениях Вятско-Камской впадины / В. А. Наумов, Б. М. Осовецкий // Литология и полезные ископаемые. - 2013.- № 3. - С. 256-273 .

30. Савко, А. Д. Эксгаляционно-осадочная металлоносность Воронежской антеклизы - новые горизонты поисков рудных месторождений в осадочном чехле. Статья 1. Интеметаллиды: локализация, типы, состав / А. Д. Савко, Л. Т Шевырев, В. В. Лоскутов // Вестник Воронеж. гос. ун-та. Сер.: Геология. -1999. - №7- С. 139-155.

Federal State Budgetary Institution A. P. Karpinsky russian Geological Research Institute, Saint-Petersburg

Engalychev S. Y., Candidate of Geological and Mineralogical Sciences, senior researcher

E-mail: sleng2005@mail.ru

Tel.: +7 (812) 3289156 